\title{
CLAY-SLAG-FLY ASH MIXTURE: PERMEABILITY ISSUES
}

\author{
Mahdi Keramatikerman \\ Engineer, Arup Australia, 61-73 Sturt Street, \\ Suncorp Tower, Townsville QLD 4810, Australia \\ Amin Chegenizadeh \\ Senior Lecturer, Department of Civil Engineering, \\ Curtin University of Technology, Kent Street, Bentley, Perth, Western Australia 6102, Australia \\ Hamid Nikraz \\ Professor, Department of Civil Engineering, \\ Curtin University of Technology, Kent Street, Bentley, Perth, Western Australia 6102, Australia.
}

\begin{abstract}
Drainage and permeability has been in center of attention of many researchers. The falling head testing was applied in this study due nature of the used soil. This study incorporates the effect of slag and fly ash changes on the permeability of mixtures. Three percentages of 5, 10, 15\% for slag and three fly ash contents of $5,10,15 \%$ have been used in this study.
\end{abstract}

Keywords - Permeability, Sand, Lime

\section{INTRODUCTION}

Permeability value in clayey soil is in the range of $10^{-8}$ $10^{-10} \mathrm{~m} / \mathrm{s}$ [1-12]. However, this is a very low rate value for the permeability value still may cause soil mechanical issues especially in the areas which require higher shear or compressive strength behaviour [13-35]. Addition of by products and cementitious products have shown that they can reduce the permeability of the soil to a lower rate and reduce the associated issues with permeability [36-54]. This study aims to investigate effect of addition of slag and fly ash on bentonite permeability.

\section{MATERIALS}

The materials which were used in this study were:

\section{a) Clay}

Bentonite was applied as clay in the mixture. The $\mathrm{Cu}$ of the bentonite was 1.3 .

\section{b) Slag}

The slag was sourced locally from a Perth supplier.

$$
\text { c) Flyash }
$$

The flyash which was employed in this study had $\mathrm{pH}=11$.

\section{PERMEABILITY TEST}

The tests were run in falling head device. The permeability was measured and recoreded for each mixes.

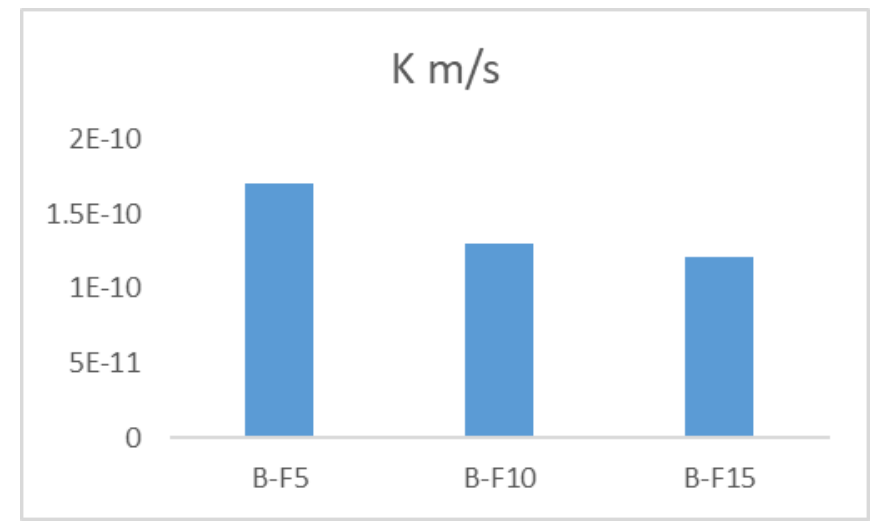

Fig. 1. Permeability of fly ash mixed with bentonite

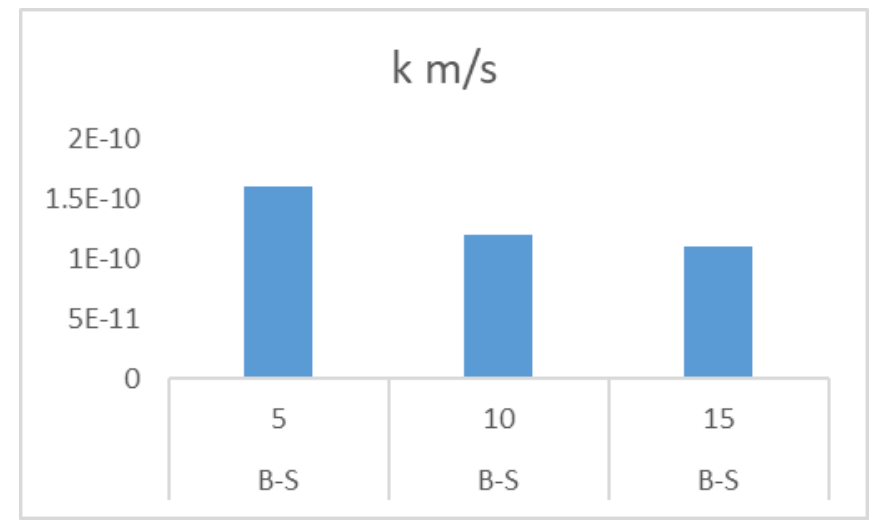

Fig. 2. Permeability of slag mixed with bentonite mixtures 


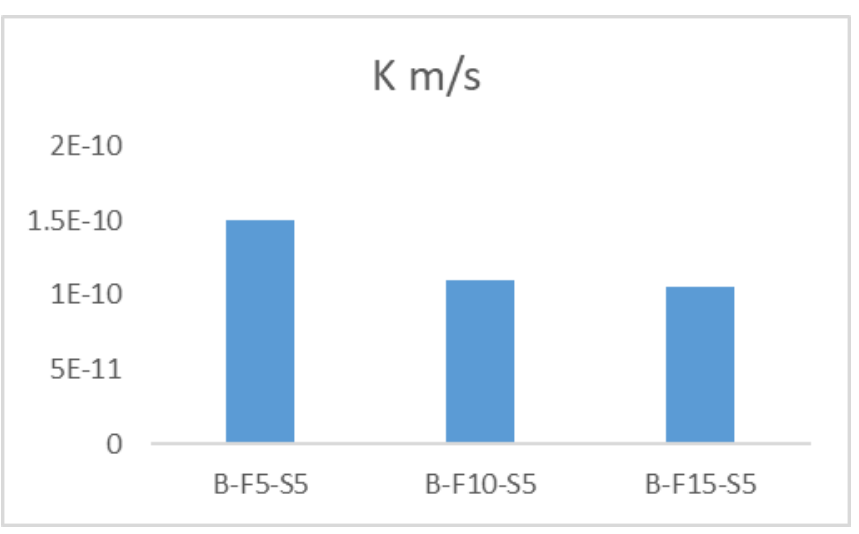

Fig. 3. Permeability of fly ash mixed with $5 \%$ slag and bentonite.

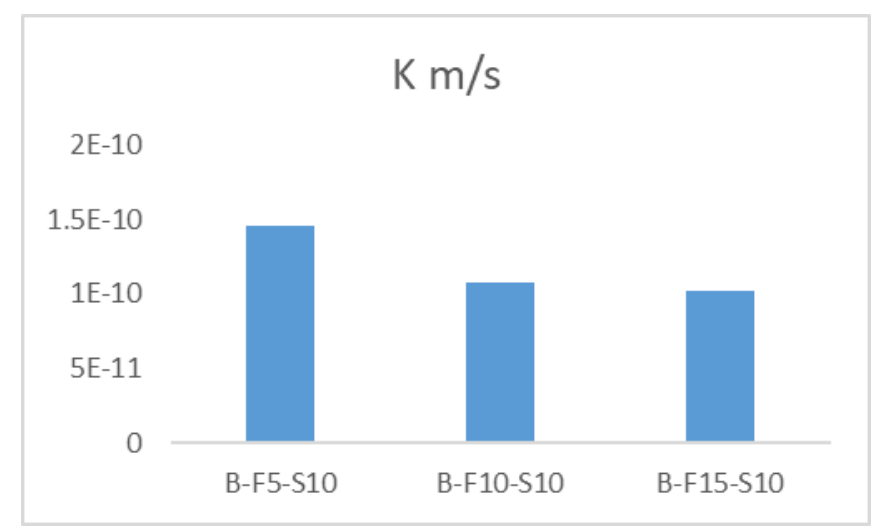

Fig. 4. Permeability of fly ash mixed with $10 \%$ slag and bentonite.

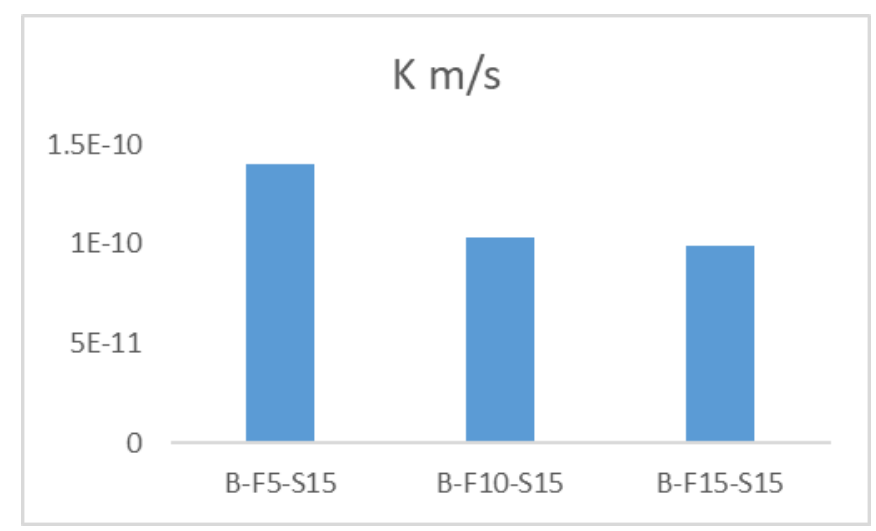

Fig. 5. Permeability of fly ash mixed with $15 \%$ slag and bentonite.

\section{CONCLUSION}

This study investigated permeability behaviour of fly ash slag mixed with bentonite. In the first pass of the study, a series tests were conducted on mixtures of fly ash and bentonite and then investigation performed on mixtures of slag and bentonite. The results showed that addition of slag and cement to bentonite reduced permeability value. Finally, the results of the final stage of the study showed that mixing both fly ash and slag decreased the permeability of sand.

\section{REFERENCES}

[1] Chapuis RP. Sand-bentonite liners: predicting permeability from laboratory tests. Canadian Geotechnical Journal. 1990 Feb 1;27(1):47-57.

[2] Chegenizadeh, A., Keramatikerman, M., Miceli, S., Nikraz, H., Salih Sabbar, A. (2020). Investigation on Recycled Sawdust in Controlling Sulphate Attack in Cemented Clay. Appl. Sci., 10, 1441.

[3] Horpibulsuk S, Yangsukkaseam N, Chinkulkijniwat A, Du YJ. Compressibility and permeability of Bangkok clay compared with kaolinite and bentonite. Applied Clay Science. 2011 Apr 1;52(1-2):150-9.

[4] Al-Rkaby AHJ, Chegenizadeh A, Nikraz H. (2017). Anisotropic strength of large scale geogrid-reinforced sand:experimental study Soils and foundations 57 (4), 557-574

[5] Horpibulsuk S, Yangsukkaseam N, Chinkulkijniwat A, Du YJ. Compressibility and permeability of Bangkok clay compared with kaolinite and bentonite. Applied Clay Science. 2011 Apr 1;52(1-2):150-9.

[6] Amiralian S, Chegenizadeh A, Nikraz H (2012) Laboratory investigation on the compaction properties of lime and fly ash composite, Proceedings of the International Conference on Civil and Architectural applications (ICCAA'2012) 79-83

[7] Pandian NS, Nagaraj TS, Raju PN. Permeability and compressibility behavior of bentonite-sand/soil mixes. Geotechnical Testing Journal. 1995 Mar 1;18(1):86-93.

[8] Keramatikerman M, Chegenizadeh A, Terzaghi S. (2019) Review on Effect of Sugarcane Bagasse Ash as an Additive in Construction Industry. 2019. EJGE. Vol.24 Bun. 02.

[9] Ameta NK, Wayal AS. Effect of bentonite on permeability of dune sand. Ejge. 2008 Jan;13:1-7.

[10] Chegenizadeh, A., \& Keramatikerman, M. (2017). Mitigating sulphate attacks in geotechnical engineering Hauppauge, New York, USA Nova Science Publishers. (pp. 1-165).

[11] Mikhail, M., Chegenizadeh, A., Keramatikerman, M., Burns, G., Terzaghi, S., Nikraz, H. (2020). Application of Cane Ash on Compressive Strength of Soil Uncovered to $\mathrm{MgSO}_{4}$. International Journal of Engineering and Advanced Technology (IJEAT) 9(4). 


\section{International Journal of Engineering Applied Sciences and Technology, 2020 \\ Vol. 4, Issue 11, ISSN No. 2455-2143, Pages 34-37 \\ Published Online March 2020 in IJEAST (http://www.ijeast.com)}

[12] Abeele WV. The influence of bentonite on the permeability of sandy silts. Nuclear and chemical waste management. 1986 Jan 1;6(1):81-8.

[13] Chegenizadeh, A., Keramatikerman, M., \& Nikraz, H. (2017). A Study on Numerical Modelling of Rigid Pavement: Temperature and Thickness Effect. International Journal of Civil and Environmental Engineering, 10(2), 265-269.

[14] Pusch R. Permeability of highly compacted bentonite. Svensk Kaernbraenslefoersoerjning AB; 1980.

[15] Chegenizadeh, A. and H. Nikraz, (2011). Composite Soil: Fiber Inclusion and Strength, Journal of Advanced Materials Research 1646

[16] Ye WM, Wan M, Chen B, Chen YG, Cui YJ, Wang J. Temperature effects on the unsaturated permeability of the densely compacted GMZ01 bentonite under confined conditions. Engineering Geology. 2012 Feb 13;126:1-7.

[17] Mikhail, M., Keramatikerman, M., Chegenizadeh, A., Terzaghi, S., Burns, G., Nikraz, H. (2020). Influence of Bagasse Ash on Compaction Behvaiour of Soil. International Journal of Innovative Technology and Exploring Engineering (IJITEE). 9(5).

[18] Milne IH, McKelvey JG, Trump RP. Semi-permeability of bentonite membranes to brines. AAPG Bulletin. 1964 Jan 1;48(1):103-5.

[19] Al-Rkaby AHJ, Chegenizadeh A, Nikraz H. (2016). Directional-dependence in the mechanical characteristics of sand: A Review International Journal of Geotechnical Engineering 10 (5), 499-509

[20] Evans JC, Fang HY, Kugelman IJ. Organic fluid effects on the permeability of soil-bentonite slurry walls. InProceedings of the National Conference on Environmental Emergencies 1985 May 14 (pp. 267-271). The Hazardous Materials Control Research Institute: Cincinnati, $\mathrm{OH}$.

[21] Keramatikerman, M., Chegenizadeh, A., \& Pu, H. (2017). Effect of atrazine contamination on compressibility and permeability characteristics of clay. Geotechnical Testing Journal, 40(6), 936-950.

[22] Chegenizadeh A, Aashish M, Nikraz H, Keramatikerman M. Sulphate Attack on CementedBentonite-Coconut Coir. Results in Engineering. 2020 Mar 3:100111.

[23] Keramatikerman, M. (2018). Investigations into Effect of By-product Binders in Improvement of Cyclic Behaviour of Soil (Doctoral dissertation, Curtin University).

[24] Keramatikerman, M., Chegenizadeh, A., \& Nikraz, H. (2018). Effect of Flyash on Post-Cyclic Behavior of Sand. Journal of Earthquake Engineering, 1-13.

[25] Keramatikerman, M., Chegenizadeh, A., Yilmaz, Y., \& Nikraz, H. (2018). Effect of Lime Treatment on Static Liquefaction Behavior of Sand-Bentonite Mixtures. Journal of Materials in Civil Engineering, 30(11), 06018017.
[26] Chegenizadeh, A., Keramatikerman, M., Dalla Santa, G., \& Nikraz, H. (2018). Influence of recycled tyre amendment on the mechanical behaviour of soilbentonite cut-off walls. Journal of cleaner production, 177, 507-515

[27] Keramatikerman M, Chegenizadeh A, Nikraz H. (2017). Experimental study on effect of fly ash on liquefaction resistance of sand Soil Dynamics and Earthquake Engineering 93, 1-6

[28] Gates WP, Nefiodovas A, Peter P. Permeability of an organo-modified bentonite to ethanol-water solutions. Clays and Clay Minerals. 2004 Apr 1;52(2):192-203.

[29] Chegenizadeh, A., Nikraz, H. (2011). "Investigation on strength of fiber reinforced clay" Advanced Materials Research 261-263, pp. 957-963.

[30] Mishra AK, Ohtsubo M, Li L, Higashi T. Effect of salt concentrations on the permeability and compressibility of soil-bentonite mixtures. JOURNAL-FACULTY OF AGRICULTURE KYUSHU UNIVERSITY. 2005 Oct $1 ; 50(2): 837$.

[31] Keramatikerman, M., Chegenizadeh, A., Nikraz, H., \& Sabbar, A. S. (2018). Effect of flyash on liquefaction behaviour of sand-bentonite mixture. Soils and foundations, 58(5), 1288-1296.

[32] Meeten GH, Sherwood JD. The hydraulic permeability of bentonite suspensions with granular inclusions. Chemical engineering science. 1994 Oct 1;49(19):324956.

[33] Chegenizadeh, A. and H. Nikraz, (2011). "Study on modulus of elasticity of reinforced clay" - Advanced Materials Research. 243-249: pp. 5885-5889, 2011.

[34] Plee D, Lebedenko F, Obrecht F, Letellier M, Van Damme H. Microstructure, permeability and rheology of bentonite-cement slurries. Cement and Concrete Research. 1990 Jan 1;20(1):45-61.

[35] Chegenizadeh, A. and H. Nikraz, (2012). Composite Clayey Sand and Short Fiber, Advanced Materials Research 383, 2764-2769

[36] Liu L. Permeability and expansibility of sodium bentonite in dilute solutions. Colloids and Surfaces A: Physicochemical and Engineering Aspects. 2010 Apr 5;358(1-3):68-78.

[37] Keramatikerman M, Chegenizadeh A, Nikraz H. Effect of Slag on Restoration Mechanical Characteristics of Ethanol Gasoline-Contaminated Clay. Journal of Environmental Engineering. 2018 Jul 1;144(7):06018001.

[38] Shirazi SM, Kazama H, Salman FA, Othman F, Akib S. Permeability and swelling characteristics of bentonite. International journal of the physical sciences. 2010 Sep 18;5(11): 1647.

[39] Chegenizadeh, A., Keramatikerman, M., \& Nikraz, H. (2018). Liquefaction resistance of fibre reinforced lowplasticity silt. Soil Dynamics and Earthquake Engineering, 104, 372-377. 
[40] Vangpaisal T, Bouazza A. Gas permeability of partially hydrated geosynthetic clay liners. Journal of Geotechnical and Geoenvironmental Engineering. 2004 Jan;130(1):93-102.

[41] Chegenizadeh A, Keramatikerman M, Panizza S, Nikraz H. (2017). Effect of powdered recycled tire on sulfate resistance of cemented clay. Journal of Materials in Civil Engineering. 2017 Oct 1;29(10):04017160.

[42] Amiralian S, Chegenizadeh A, Nikraz H (2012) Laboratory investigation on the effect of lime on compressibility of soil, Proceedings of the International Conference on Civil and Architectural applications (ICCAA'2012) 89-93

[43] Edil TB, Erickson AE. Procedure and equipment factors affecting permeability testing of a bentonite-sand liner material. InHydraulic barriers in soil and rock 1985 Jan. ASTM International.

[44] Chegenizadeh A, Keramatikerman M, Panizza S, Nikraz H. (2017). Effect of powdered recycled tire on sulfate resistance of cemented clay. Journal of Materials in Civil Engineering. 2017 Oct 1;29(10):04017160.

[45] Keramatikerman M, Chegenizadeh A, Nikraz H. Shear strength characteristics of over-consolidated clay treated with ggbfs. Australian Geomechanics Journal. 2018;53(2):141-9.

[46] Mazzieri F, Pasqualini E. Permeability of damaged geosynthetic clay liners. Geosynthetics International. 2000;7(2):101-18.

[47] Keramatikerman, M., Chegenizadeh, A., Nikraz, H. How Ground Improvement Addresses the United Nation Sustainable Development Goals: A Review. Current Trends in Civil \& Structural Engineering 5(3): 2020. CTCSE.MS.ID.000613.

DOI: 10.33552/CTCSE.2020.05.000613

[48] Gipson AH. Permeability testing on clayey soil and silty sand-bentonite mixture using acid liquor. In Hydraulic Barriers in Soil and Rock 1985 Jan. ASTM International.

[49] Keramatikerman M, Chegenizadeh A. Effect of particle shape on monotonic liquefaction: Natural and crushed sand. Experimental Mechanics. 2017 Oct 1;57(8):1341-8.

[50] Keramatikerman, M., Chegenizadeh, A., \& Nikraz, H. (2017). An investigation into effect of sawdust treatment on permeability and compressibility of soil-bentonite slurry cut-off wall. Journal of Cleaner Production, 162, $1-6$.

[51] Chegenizadeh, A., Keramatikerman, M., \& Nikraz, H. (2016). Flexible pavement modelling using Kenlayer. EJGE, 21, 2467-2479.

[52] Chegenizadeh, A., Keramatikerman, M., Nikraz, H., Importance of Microstructural Analysis in Experimental Soil Stabilization. Global Journal of Engineering Science. 4(5): 2020.

[53] Kelessidis VC, Tsamantaki C, Pasadakis N, Repouskou E, Hamilaki E. Permeability, porosity and surface characteristics of filter cakes from water-bentonite suspensions. WIT Transactions on Engineering Sciences. 2007 May 11;56:173-82.

[54] Egloffstein TA. Natural bentonites-influence of the ion exchange and partial desiccation on permeability and self-healing capacity of bentonites used in GCLs. Geotextiles and Geomembranes. 2001 Sep 1;19(7):42744. 